
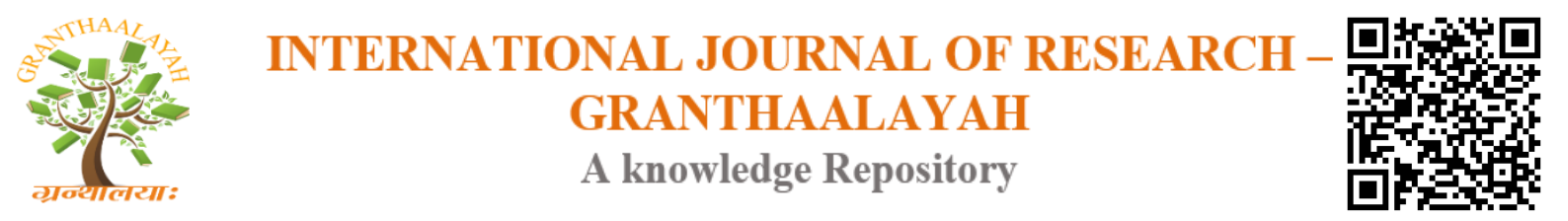

Management

\title{
ASSOCIATION BETWEEN DEMOGRAPHIC FACTORS AND ATTITUDE TOWARDS CREDIT CARD USAGE, AMONG THE HOUSEHOLDS IN KARAVEDDY DIVISIONAL SECRETARIAT IN JAFFNA DISTRICT - SRI LANKA
}

\author{
T.Athiyaman ${ }^{1}$, V.A.Subramaniam ${ }^{2}$ \\ ${ }^{1}$ Senior Assistant Registrar Centre for Open and Distance Learning University of Jaffna \\ ${ }^{2}$ Senior Lecturer, Department of Financial Management, Faculty of Management Studies and \\ Commerce University of Jaffna
}

\begin{abstract}
Technological developments play a significant role in accelerating economic development of nations. One of the important evidence for the above statement is the payment system using the card. This payment instrument is called as credit card. The credit card, also referred to as "plastic money" represents a contemporary payment system in the modern world. It can be stated as a payment tool that provides to the people the possibility of purchasing needed goods or services, without making any payment at that moment of purchase, by allowing them to make such payment at a later time, without charging any additional financial burden.
\end{abstract}

Keywords: Credit Card; Households; Demographic; Factors.

Cite This Article: T.Athiyaman, and V.A.Subramaniam. (2018). "ASSOCIATION BETWEEN DEMOGRAPHIC FACTORS AND ATTITUDE TOWARDS CREDIT CARD USAGE, AMONG THE HOUSEHOLDS IN KARAVEDDY DIVISIONAL SECRETARIAT IN JAFFNA DISTRICT - SRI LANKA.” International Journal of Research - Granthaalayah, 6(6), 16-21. https://doi.org/10.29121/granthaalayah.v6.i6.2018.1330.

\section{Introduction}

\subsection{Background of the Study}

Credit card proposes a variety of attractive facilities to users. The credit card to be one of the sources of money for the holder, when there is such a sudden transaction (Brito and Hartley, 1995). Therefore, credit card will create an additional financial source. Credit card can make the holder feel more comfortable without too much holding cash (Khare, Khare, and Singh, 2012 and Lee and Kwon, 2012). Credit card will also show the symbolize of lifestyle and perceptions of social status for self actualization that related to consumptive benefit (Medina and Chau, 1998). Self actualization demonstrates the highest achievement to fulfill everyone's needs and desires when using credit card. 
The first credit card in world was introduced in 1920s in United States of America. However, according to the Central Bank of Sri Lanka, credit cards were introduced to Sri Lanka by Commercial Banks in 1989. In the case of the Northern and Eastern provinces of Sri Lanka the credit card system became popular after the end of local war situation. At present, there is a rapid increase in the usage of credit cards in the entire parts of the Island.

\subsection{Research Problem}

Generally, people use credit card to feel happy because they can fulfill family's needs and wants. There will be no problem, although the use of credit cards lead to increased debt. Therefore, they maybe want to apply for increasing credit limit and try all types of credit cards. Usually, this is done by woman (Mottola, 2012), who has high income, and already married (Bulu and Koprulu, 2012). Kaynak and harcar (2001) investigated consumer attitudes and intentions towards credit card ownership in turkey and found that the age group of between 36 and 45 is more likely to own credit cards than any other age group. Therefore, analyzing the association between demographic factors and attitude towards credit card usage among the households have become much more important in the context of increasing trend of credit card usage rather than the conventional credit schemes. Thus, this study attempts to answer the following question.

"What type of relationships exist between the demographic factors and attitude towards credit card usage among the households in Karaveddy Divisional Secretariat in Jaffna District - Sri Lanka?"

\subsection{Objective of the Study}

1) The objective of this study is to identify the association between the demographic factors and the attitude towards credit card usage among the Households in Karaveddy Divisional Secretariat in Jaffna District - Sri Lanka.

2) To provide suggestions for improving the efficiency and effectiveness of credit card system.

\subsection{Significance of the Study}

At present credit card usage is in increasing trend. However, Credit card debts have become a focus of academic and public policy in recent years with the growth of the fraction of households carrying credit card debts and the increase in magnitude of credit card debts (Erdem 2008; Amin 2012; Shu \& Cheng 2012). Findings from previous researches indicate that demographic characteristics influence households' decision of borrowing on credit card and amounts of outstanding credit card balance significantly, including age; race; and financial status, such as income and net worth (Shu \& Cheng 2012). Thus, findings of the study will support households to improve the proper usage of credit cards. Similarly, the findings of the study will also help to credit card issuing companies to design their marketing strategies.

\subsection{Empirical Review}

Zuroni \& Lim (2012) found that gender, monthly income and personal financial knowledge influence the credit card practices among working adults in Malaysia. Kinsey (1981) indicates that 
the probability of having credit cards and the number was correlated highly with age and occupation. Ahmed, Amanullah \& Hamid (2009) examined the shift of Pakistani consumers towards the use of plastic money, with emphasis on credit cards and found that a positive relationship between the income level of a person and his/her possession of the credit card. It was also concluded that the profession of the person seems to play a very interesting role with their behavior towards credit cards. Atthaphol (2010) found that education level and the length of working experience are the most important variables that associate with the intention to use credit cards. Ucal, Neil \& Çankaya (2011) concluded that gender does affect credit card usage among Turkish university students and the most interesting result revealed from this study was that more women than men felt it was prestigious to use credit cards. Themba and Tumedi (2012) found that credit card ownership and usage were highly related with education, gender, and marital status. Safakli (2007) concluded that education and family income play an important role in credit card selection.

\section{Materials and Methods}

This study attempts to identify the association between demographic factors of households in Karaveddy Divisional Secretariat in Jaffna District - Sri Lanka and their attitude toward credit card usage. The demographic factors such as gender, age, civil status, educational level, occupation and income are considered as independent variables whereas attitude toward credit card usage is considered as dependent variable. Attitude toward credit card usage will be measured in terms of willingness to apply until the maximum credit limit, usage frequency per month, amount spent through credit card and method of paying outstanding balance.

\subsection{Hypotheses}

The following hypotheses are formulated for the study.

$\mathrm{H}_{0}$ : There is no significant association between demographic factors of households in Karaveddy Divisional Secretariat in Jaffna District - Sri Lanka and their attitude towards credit card usage. $\mathrm{H}_{1}$ : There is significant association between demographic factors of households in Karaveddy Divisional Secretariat in Jaffna District - Sri Lanka and their attitude towards credit card usage.

\subsection{Sample of the Study and Data Collection}

It is a primary data-based study and the relevant data were collected through a structured questionnaire. The target population is households in the Karaveddy Divisional Secretariat holding credit cards. Regarding the sampling frame, due to the legal legislations on banking secrecy, is difficult to define the number of target population. Due to this reason, when deciding sampling design researchers have to rely on non probability sampling techniques and the convenience sampling method was selected in which method it is also easy to reach samples and to collect necessary data (Cooper and Schindler, 2001 and Craig and Douglas, 2000). The sample size was 150 households with credit card holding in Karaveddy Divisional Secretariat. Karaveddy Divisional Secretariat can be considered as a semi urban area and the density of financial service providers in the Divisional Secretariat is very high. In this division, eight banking institutions and five financial companies provide their financial services. 


\section{Method of Analysis}

Percentage analysis and Chi-square test were used in the study and mainly Chi-square test was used to identify the association between demographic factors and attitude towards credit card usage.

\section{Profile of Respondents}

The number of respondents of the study based on the demographic factors are given in table 1 .

Table 1: Profile of Respondents

\begin{tabular}{|c|c|c|c|}
\hline \multicolumn{2}{|c|}{ Demographic Factors } & \multirow{2}{*}{$\begin{array}{l}\text { Number of Respondents } \\
89\end{array}$} & \multirow{2}{*}{\begin{tabular}{|l|} 
Percentage \\
$61.8 \%$ \\
\end{tabular}} \\
\hline Gender & Male & & \\
\hline & Female & 55 & $38.2 \%$ \\
\hline \multirow[t]{5}{*}{ Age } & $<25$ & 19 & $13.2 \%$ \\
\hline & $25-35$ & 34 & $23.6 \%$ \\
\hline & $36-45$ & 35 & $24.3 \%$ \\
\hline & $46-55$ & 38 & $26.4 \%$ \\
\hline & $>55$ & 18 & $12.5 \%$ \\
\hline \multirow{2}{*}{ Civil Status } & Single & 31 & $21.5 \%$ \\
\hline & Married & 113 & $78.5 \%$ \\
\hline \multirow[t]{6}{*}{$\begin{array}{l}\text { Educational } \\
\text { Qualification }\end{array}$} & Below G.C.E.O/L & 7 & $4.9 \%$ \\
\hline & G.C.E.O/L & 23 & $16.0 \%$ \\
\hline & G.C.E.A/L & 55 & $38.2 \%$ \\
\hline & Diploma & 12 & $8.3 \%$ \\
\hline & Graduate & 37 & $25.7 \%$ \\
\hline & Post Graduate & 10 & $6.9 \%$ \\
\hline \multirow[t]{4}{*}{ Occupation } & Self Employed & 43 & $29.9 \%$ \\
\hline & Private Sector Employees & 32 & $22.2 \%$ \\
\hline & State Sector Employees & 61 & $42.4 \%$ \\
\hline & Retired & 8 & $5.5 \%$ \\
\hline \multirow[t]{5}{*}{ Monthly Income } & $<25000$ & 21 & $14.6 \%$ \\
\hline & $25000-35000$ & 43 & $29.9 \%$ \\
\hline & $35001-45000$ & 51 & $35.4 \%$ \\
\hline & $45001-55000$ & 16 & $11.1 \%$ \\
\hline & $>55000$ & 13 & $9.0 \%$ \\
\hline
\end{tabular}

According to the Table 1, 61.8\% of the respondents are male and $38.2 \%$ of them are female. In addition, $78.5 \%$ of the respondents are married ad $38.2 \%$ of the respondents are with G.C.E.A/L qualification.

\section{Analysis and Interpretation}

An attempt was made to test the Hypothesis which states the association between demographic factors and attitude towards credit card usage. 
Table 2: Relationship between Demographic Factors and Attitude towards Credit Card Usage

\begin{tabular}{|l|l|l|l|l|l|}
\hline $\begin{array}{l}\text { Demographic } \\
\text { factors }\end{array}$ & $\begin{array}{l}\text { Pearson Chi Square } \\
\text { Value }\end{array}$ & df & $\begin{array}{l}\text { Asymp. Sig. } \\
\text { (2sided) }\end{array}$ & $\begin{array}{l}\text { Significant or Not } \\
\text { Significant }\end{array}$ \\
\hline Gender & 12.718 & 3 & 0.005 & Significant \\
\hline Age & 26.467 & 15 & 0.033 & & Significant \\
\hline Civil Status & 3.117 & 3 & 0.374 & Not Significant \\
\hline $\begin{array}{l}\text { Educational } \\
\text { Qualification }\end{array}$ & 21.325 & 15 & 0.127 & & Not Significant \\
\hline Occupation & 16.026 & 9 & 0.046 & Significant & \\
\hline Income & 22.009 & 12 & 0.037 & Significant & \\
\hline
\end{tabular}

Table 2 reveals the results of the Chi-Square test conducted to identify the association between demographic factors and attitude towards credit card usage.

According to the Table 2 there is an association between demographic variables such as gender, age, occupation and income; and attitude towards credit card usage. However, there is no association between other demographic variables such as civil status and educational qualification; and attitude towards credit card usage. Therefore, the hypothesis is accepted partially.

Generally, females are more precautious than males and it is reflected in the attitude towards credit card usage. In addition, younger people use credit cards frequently and they tend to apply until the maximum credit limit. But the most of the elder people use credit cards in urgent situations only and they are very cautious in using credit cards. Further, there is an association between occupation and attitude towards credit card usage. In practice, credit card issuers provide more emphasis for the occupation of the household in assessing their applications and in determining the maximum credit limit. Occupation plays a significant role in determining the repayment capacity and payment methods of households. Finally, there is an association between income and attitude towards credit card usage. As in the case of occupation, credit card service providers consider income as a main factor for evaluating the applications of households and decides the maximum limit based on their income. Households with higher level of income use credit card freely without the fear of repayment, whereas households with lower level of income have the fear of repayment and limit their credit card usage based on their income level.

\section{Conclusion}

Usage of credit cards offer various benefits to households and at the same time unplanned usage of credit cards causes various difficulties to households such as unnecessary interest payments and penalties for late payments. Thus, a proper understanding on the association between demographic factors of households and attitude towards credit card usage supports to increase the efficient and effective usage of credit cards. According to the results of the study, there is an association between demographic variables such as gender, age, occupation and income; and attitude towards credit card usage. This finding will support the credit card service providers to design their products and marketing strategies in future. 


\section{References}

[1] Ahmed, A., Amanullah, A., \& Hamid, M. (2009). Consumer perception and attitude towards credit card usage: A study of Pakistani consumers. Journal of Comparative International Management, 12(1), 47-57.

[2] Amin, H. 2012. Patronage factors of Malaysian local customers towards Islamic credit cards. Management Research Review 35(6): 512-530

[3] Atthaphol, J. (2010). Credit card use among Bangkok cardholders: An exploration into credit card attitudes, Debt and strategy improvement. ABAC Journal, 30(3), 15-29.

[4] Brito, D. L., and Hartley, P. R. (1995). Consumer Rationality and Credit Cards. The Journal of Political Economy. 103(2),400-433.

[5] Bulu, Y. dan Koprulu, O. (2010). Credit Card Market and Socio-Economic Background of Card Holders: A Case Study from Turkey. International Journal of Economic Perspectives. 4(4),623633.

[6] Cooper, Donald R., and Pamela S. Schundler, 2001, Business Research Methods. 7th

[7] Craig, C. Samuel and Susan P. Dauglas, 2000, International Marketing Research. 2th

[8] Edition. Chicester : John Wiley\& sons, Ltd.

[9] Edition. Mc. Hill International Edition.

[10] Erdem, C. 2008. Factors affecting the probability of credit card default and the intention of card use in Turkey. International Research Journal of Finance and Economics 18:159-171.

[11] Hussin, S. R., Kassim, S. and Jamal, N. (2011) Credit Card Marketing Strategy and Its Impact on usage among Malaysians. Proceedings of the 15th National MACFEA Seminar, 1-23.

[12] Jusoh, Z., \& Lin, L. Y. (2012). Personal financial knowledge and attitude towards credit card practices among working adults in Malaysia. International Journal of Business and Social Science, 3(7).

[13] Kara, A., Keynak, E. and Kucukemiroglu, O. (1994) Credit Card development Strategies for the youth Market: the use of Conjoint analysis, International Journal of Bank Marketing, 12(6), 30-36.

[14] Kaynak, E., \& Harcar, T. (2001). Consumers' attitudes and intentions towards credit card usage in an advanced developing country. Journal of Financial Services Marketing, 6(1), 24-39.

[15] Khare, A., Khare, A., and Sigh, S. (2012). Factors Affecting Credit Card Use in India. Pacific Journal of Marketing and Logistics. 24(2),236-256.

[16] Kinsey, J. (1981). Determinants of credit card accounts: An application of Tobit analysis. Journal of consumer Research, 8(2), 172-182.

[17] Lee, J. and Kwon, K. N. (2002). Consumers' Use Of Credit Card: Store Credit Card Usage as an Alternative Payment and Financing Medium. Journal Of Consumer Affairs. 36(2), 239-262.

[18] Medina, J. F. and Chau, C. T. (1998). Credit Card Usage Behavior between Anglos and Hispanics. Hispanic Journal of Behavioral Science. 20(4), 429-448.

[19] Motivating Factors of Credit Card Usage and Ownership: Evidence from Northen Cyprus. Investment Management and Financial Innovations. Vol. 4, Iss. 4. Pp. 133-143.

[20] Mottola. G. R. (2012). In Our Best Interest: Women, Financial Literacy and Credit Card Behavior. Insights: American Financial Capability, 1-6.

[21] Shu, W. \& Cheng, C.Y. 2012. How to improve consumer attitudes toward using credit cards online: An experimental study. Electronic Commerce Research and Applications 11(4): 335-345.

[22] Themba, G., \& Tumedi, C. B. (2012). Credit Card Ownership and Usage Behaviour in Botswana. International Journal of Business Administration. Safakli, O. V. (2007).

[23] Ucal, M. O., Neil, M. L., \& Çankaya, S. (2011). Effects of gender on credit card usage among university students in Turkey. African Journal of Business Management, 5(22), 9023-9030.

\footnotetext{
*Corresponding author.

E-mail address: fmsmani@yahoo.com
} 